\title{
Nature of the state economic expanded functions in the Brazilian economy*
}

\author{
Natureza das funções econômicas alargadas \\ do Estado na economia brasileira
}

NIEMEYER ALMEIDA FILHO $* *$

RESUMO: O artigo discute a dinâmica da acumulação de capital nas economias da América Latina. A hipótese é que nessas economias o papel do Estado é comparativamente mais amplo do que nas economias dos centros do capitalismo, por razões estruturais. $\mathrm{O}$ argumento baseia-se principalmente em Marx e Kalecki, além de elementos históricos das economias da América Latina, particularmente da economia brasileira. Em seguida, o artigo explora as consequências dinâmicas desta natureza em nível nacional, concluindo que esta condição dá um maior grau de instabilidade.

PALAVRAS-CHAVE: desenvolvimento nas economias da América Latina; o papel do Estado na acumulação; dinâmica de acumulação; economia brasileira.

ABSTRACT: The paper discusses the dynamics of capital accumulation in Latin America economies. The hypothesis is that in these economies the role of the State is comparatively broader than in the economies of the centers of the capitalism by structural reasons. The argument is mainly based on Marx and Kalecki, besides historical elements of Latin America economies, particularly the Brazilian economy. Then the paper explores the dynamics consequences of this nature at the national levels, concluding that this condition gives a higher degree of instability.

KEYWORDS: development in Latin America economies; role of the State on accumulation; dynamic of accumulation; Brazilian economy.

JEL Classification: P16; O54; O10.

\footnotetext{
* This article is excerpted in part of Almeida Filho (2013), in which we explore in greater depth the specific propositions Marini.

** Instituto de Economia, Universidade Federal de Uberlândia, Uberlândia, MG - Brasil. E-mail nafilho2011@gmail.com. Submetido: 11/Agosto/2014; Aprovado: 19/Fevereiro/2015.
} 


\section{INTRODUCTION}

The publication of Marini's book Dialectic of Dependency in Portuguese (Marini, 2000) and a number of his works ${ }^{1}$ sparked significant recovery of their theoretical propositions and policies in a new historical period of development in Brazil.

Examples of this recovery are the books of Traspadini and Stédile (2005), Valencia et al. (2009), Almeida Filho (2012), Ferreira et al. (2012) and several articles in journals. Marini is one of the seminal references of the Marxist theory of dependency. For him, the fundamental and decisive feature of the dependent economies of Latin America is the dominance of the "superexploitation of the labour force," determined by the value transfer to the dynamic Centers of capitalism.

In Marini's perception, superexploitation of the labour force in the Latin American periphery is a real and intrinsic feature, only surpassed in other social order. His arrest and formulation are built under the Marxist thought, assuming the superexploitation as a category. Moreover, there is clear political intention to highlight the perversity of Latin American development, perhaps, for this reason his ideas have been (and still are) subject to huge controversy and contestation.

In other works (Almeida Filho, 2012, 2013) we specifically discussed this interpretation, its consequences and update requirements. In this article, we will focus only on a note that follows their propositions: Marini sustain that super-exploitation is a major determinant of the extraordinarily concentrated distribution of income and wealth of Latin America's economies compared to other regions.

In Brazil, this concentration gains contours of paroxysm, raising the economy to the top of the international ranking of inequality. ${ }^{2}$ Marini pointing is to say, in other words, that wages paid to Brazilian workers are comparatively lower than those paid in the central countries in productive branches and similar technologies companies. And, by extension, to say that the share of wages in aggregate income is also lower, considering all other elements of the functional income distribution as unchanged.

Taking this appointment as a starting point, we discuss its consequences to the dynamics of the economy: in the context of capital circulation, the relative concentration of income and wealth requires greater relative scale of productive and unproductive capitalists' expenditures for each level of growth, as spending on workers' consumption will be relatively minor, by lower relative level of wages, depressing the Keynesian multiplier.

\footnotetext{
${ }^{1}$ The works of Marini are organized on a site - Marini, Writings. He is free to access: http://www. marini-escritos.unam.mx.

${ }^{2}$ Data World development report 2006: equity and development show progress in the Brazilian comparative condition, coming out of a second position in the world inequality ranking to tenth. In the study, Brazil ranks as the most unequal in Latin America. Another reference is Ferreira (2007) where there is a discussion of the causes for reducing inequality in Brazil.
} 
The articles' hypothesis is that in the economies of Latin America this tightening of capitalist spending will, in significant part, supplied by resources and state actions. The reasons can be found remotely on technical and financial limitations of capital units that operated in these economies over to capitalism transition period and the 1970s onwards, in the State of the actual operation characteristics, historically sympathetic to the particular interests of fractions the capital. Of course, the technical and financial limitations of the capital were in part overcome, however keeping a logical operation in which the root is applications that provide rapid return and low risk. ${ }^{3}$

To investigate this issue the paper is organized into two sections. In the first, we discuss the dynamic implications of the high concentration of income and wealth. In the second section, there are notes on the implications for the organization and operation of the state, including a specific form of dispossession within the meaning given to the term by Harvey (2004). ${ }^{4}$

\section{THE DYNAMIC IMPLICATIONS OF THE EXTRAORDINARY CONCENTRATION OF INCOME AND WEALTH}

The dynamic implications of very low wages are mainly for limiting the potential growth scale and instability on the economy, as a smaller share of wages in national income recurrently requires productive and unproductive expenditures compensation. ${ }^{5}$

In Marx, at the high level of abstraction in which he formulates the possibility of reproduction of the production process, the levels of wages have repercussions both in terms of production and the circulation of capital.

In terms of capital movement, other things equal, lower pay levels have the implication of increasing the scale of productive and unproductive consumption necessary for the accumulation process takes place in a broad way, or require sale of part of production in foreign trade. ${ }^{6}$

If, for analytical purposes, we can imagine a closed economy, a fall in the

\footnotetext{
3 This discussion is partly held in Almeida Filho and Paulani (2011).

${ }^{4}$ As will be detailed ahead, the dispossession in Harvey makes sense similar to primitive accumulation, though, for him, a process inherent in the historical capitalist development.

${ }^{5}$ The meaning of the word is production of consumer goods aimed at producing: inputs, capital goods and buildings.

${ }^{6}$ The definition of productive or unproductive labour is related to the added value, the surplus. There is no connotation of social irrelevance. See Carcanholo (2008). This theme is originally treated in Marx in high level of abstraction in which contemporary issues are not answered. Considering the huge difference that exists in the labour market, we must make the definition more concrete levels. In principle the impact there is to this Article shall take the scope of production as part of added value production. Therefore, it is considered not only working in industry and agriculture itself, but also services sector workers, with qualifications that are made in the article cited here.
} 
general level of wages will impose equivalent increase in the productive consumption (investments) and unproductive (consumer goods) of the capitalists for the global accumulation process does not slow down your pace.

Marx did not analyse the implications of a general fall in wages by indirect mechanisms such as unfavourable worker legislation, because the focus has always been to show the nature of the capital accumulation process. In this case, a relevant factor is the existence of the industrial reserve army, which can be taken as a general reference of capitalism, regardless of the characteristics of each social formation.

However, in the twentieth century, this issue will be presented subsequently when the global capitalist system achieves greater degree of maturity in which a significant number of companies had already entered the advanced stage of production, with established industries.

In the scope of Marxism, the question will take the form of the debate about the nature of periodic crises, if consumption-crisis or capital overproduction. Nevertheless, this issue is also present in the discussion of the principle of effective demand made by Keynes (1985) and Kalecki (1977).

It's in Kalecki's formulation, in a distinct and more concrete level of abstraction than that formulated by Marx, that the implications of a fall in wage levels could be easily understood. ${ }^{7}$

Kalecki formulate the capitalist dynamic from a distributive scheme that allows one to set up a system of equations in which the distribution of income has implications. See Table 1.

Table 1

\begin{tabular}{|c|c|c|c|c|}
\hline Departments & I & II & III & Total \\
\hline Profit & P1 & P2 & P3 & P \\
\hline Wages & W1 & W2 & W3 & W \\
\hline Income & I & Cc & CW & Y \\
\hline
\end{tabular}

Source: Extracted from Kalecki $(1977$, p. 1)

In this accounting framework, the national income $\mathrm{Y}$ can be obtained from the perspective of spending, or from the perspective of income:

$$
\begin{aligned}
& \mathrm{Y}=\mathrm{I}+\mathrm{Cc}+\mathrm{CW}=\mathrm{P}+\mathrm{W} \\
& \text { And, } \\
& \mathrm{Y}=\text { income } / \text { national product } \\
& \mathrm{I}=\text { productive spending or aggregate investment }
\end{aligned}
$$

\footnotetext{
${ }^{7}$ Although the theoretical analysis of Kalecki to happen, all the time, in prices, and with the passage of values to controversy prices under Marxism, it is assumed here that the different positions on this issue does not change in essence the central argument of impact that the level of wages has for capitalist dynamics.
} 
$\mathrm{Cc}=$ consumption of the capitalists

$\mathrm{Cw}=$ workers' consumption

$\mathrm{P}=$ profits and

$\mathrm{W}=$ wages

The purpose of this tablean is to show that the variable I (investment) is the most relevant in determining the level of national income $\mathrm{Y}$, considering given the distribution of income in sectors (I, II and III). This distribution is focus and outcome of the political dispute between workers and capitalists, consistent with the general formulation of Marx.

The prominence given to the investment does not take place for its quantitative importance but because it is the variable subject to fluctuations resulting from capital accumulation conditions. Kalecki, as Keynes, assumes that the social consumption expenditures are stable for habits and limitations of income. ${ }^{8}$ However, in Kalecki, the social consumption is divided into two variables, corresponding to the expenses of workers and capitalists.

Following Marx and according to the historical process, he will consider that workers consume all income, and therefore have high propensity to consume. It can be interpreted that in the case of the capitalists the stability in consumption is by social habits.

Therefore, if we compare two economies with the same level of national income $\mathrm{Y}$, but with different income distributions, it is easy to see that for an added level of lower wages it would be required a higher level of profits and investment.

Table 2: Domestic Product - comparism between two hypotetical economies

\begin{tabular}{|c|c|c|c|c|}
\hline Income & The Economy & Economics B & Demand & \\
\hline Total wages & 40 & 55 & Workers' Spent & Consumption of workers \\
\hline Total profits & 60 & 45 & Capitalist's Spent & $\begin{array}{c}\text { Consumption of } \\
\text { the capitalists }\end{array}$ \\
\cline { 3 - 5 } & 100 & 100 & & Investment \\
\hline National income & 100 & & & \\
\hline
\end{tabular}

Source: Source: author's elaboration.

In Table 2, the departments I, II and III correspond to the production of goods, capitalist consumer goods and consumer goods workers. A general decrease in the level of wages implies fall in the participation of the department III in aggregate income, because the workers' consumption decreases. For that income remains the

\footnotetext{
${ }^{8}$ See Possas (1987).
} 
same, it is necessary a growth in production in the departments I and II at a lower wage levels.

In these two departments, different from the department III whose profit expectations and expenses are established subordinate to the current changes in wages, spending decisions are determined by profit expectations in the whole system, so by elements that are not configured by previous income.

Of course, at the level in which Kalecki theorizes this process, an important source of compensation could be the foreign trade. Still, if we imagine two economies with stable productive international inserts, the differences in income distribution imply differences also in investment levels. ${ }^{9}$

Another possibility, not suggested by Marx or by Kalecki in this tableau, is unproductive spending (in the Marxist sense) made by the State. In a contemporary equation this would be expressed as:

$$
\mathrm{Y}=\mathrm{C}+\mathrm{I}+\mathrm{G}
$$

Thus, a higher spending on investments and current government expenditure (State) would compensate the insufficient private spending.

\section{IMPLICATIONS FOR THE MODE OF OPERATION OF THE STATE}

Given the theoretical references developed in the second section, it is possible to deepen the discussion of specific features of the dependent economies of Latin America, the focus of this article.

For this, let us take Harvey's (2004) appointment. In discussing the characteristics of what he calls "New Imperialism", he names dispossession the phenomenon of direct transfer of public resources to private sector in periods of capitalist cyclical crises. This phenomenon differs from the regular indirect transfer of resources to the private sector that takes place by capitalism's structural links, for example, public spending on Education, Health and Safety, which reduce the direct cost of reproduction of labor power.

The dispossession is similar to what is inscribed in Marxist literature as primitive accumulation, although as an endogenous characteristic that is repeated in circumstances of a threat of disruption of the capital accumulation process.

This is an interesting argument used by him to explain the actions of the State in the US and other countries affected in general by the 2007-2008 crises, to support the private capital through the transfer of public resources, injecting capital

\footnotetext{
${ }^{9}$ Of course, imagining that there is no external impediment absorption of goods produced, regardless of the nature of consumer goods or capital goods.
} 
into banks and large enterprises..$^{10}$ In this sense, this would be a countercyclical action adopted to soften and shorten the periodic crises of capital.

The idea is that the dispossession is structural in Latin America, the result of specific development conditions. This means that the dispossession, as well as being a typical phenomenon of these capital crises mentioned by David Harvey, is part of the development process in the periphery. Therefore, these resource transfers to private capital are inherent in the dynamics of accumulation (Almeida Filho and Paulani, 2011). The mechanisms are diverse, including tax cuts, favored funding, use of permissions and ownership of government securities by banks in monetary management, land tenure as active, among others. Access is not homogeneous by size of capital, with proportionally larger depending on the scale and the operating sector of each type of capital.

These direct and structural transfers give the Latin America periphery private capital a "premium" of risk, a kind of compensatory profit. For this reason, the local, regional, capital "hesitates" to respond the imposition placed in theory of economic dynamics at his expense, with his own resources and sources, as developed before over the first section. The levy is due to the general level of relatively lower wages that requires more capitalist productive consumption (investment) for certain income levels or product.

It is important to note that the historical development of capitalism is not homogeneous in all of Latin America, so that this "hesitation" goes for the diversified economies and advanced financial systems, such as the Brazilian economy. Thus, the mechanisms will depend on the conditions of each economy.

In the Brazilian economy, the main prize is given by the privileged status of financial investments without risk returns, which function as an opportunity cost to private capital, which may thus require much higher investment earnings in comparison to the Centers economies.

On the other hand, different interpretations of Latin American development, such as from Ruy Mauro Marini and Celso Furtado, show that the insertion of Latin American economies in the global system is historically dependent and specialized. In addition, following Marini, the insertion determines the characteristics and the dynamics of accumulation in which the growing extraction of surplus value is predominantly via the increased degree of exploitation mainly the absolute surplus value (increased journey or intensification of work); in contrast, in the Centers of capitalism dominates the relative surplus value extraction. Thus, while the Centers increased added value is basically the result of productive innovations in Latin American periphery innovations are incorporated with lags, as production modernization, predominantly expanding the scale of production with intensive use of natural resources (Marini, 2000, pp. 113-119).

This limitation posed by the domestic private capital operation can be overcome by opening up to foreign capital and / or direct state involvement in the

${ }^{10}$ In this regard, see Eichengreen (2015). 
production process. Historically, you can register both. However, the distinguishing feature of the economies of the region is the enlargement of state functions, particularly in national economies in which the natural resource is significant. The sense that we are giving to the enlargement idea is to charge for productive functions that are regularly met by the private sector in the Centers of capitalism.

Even so, there are inherent limitations to the complement the state is able to perform because their funding resources mainly depend on the scale of national accumulation and government revenues. In other words, if the dynamism of the economy is down, there is a direct impact on available public resources. Note, also, that the productive functions of the state, once established, become autonomous, in the form of public companies, many of them covered almost entirely by the market. This means that the scope of the facilities to build the state can have will vary in proportion to the complexity and differentiation that each dependent economy has achieved.

In the specific case of the Brazilian economy, these extended functions reached a climax to cover all the infrastructure production in the 1970s, falling later in the 1990s to the supply of energy, communications and services in general, although in the latter case, these functions are particularly focused on the financing of investment by public banks. On Table 3 below you can see the relative importance of state for determining the aggregate investment (GFFC) and therefore of national income.

Table 3: Participation of State, Public Administration and

Public Sector in Gross Formation of Fixed Capital

(in $\mathrm{R} \$$ million, current)

\begin{tabular}{|c|c|c|c|c|c|c|}
\hline $\begin{array}{c}\text { Items - } \\
\text { Year }\end{array}$ & $\begin{array}{c}\text { State } \\
\text { (A) }\end{array}$ & $\begin{array}{c}\text { Public Adm. * } \\
\text { (B) }\end{array}$ & $\begin{array}{c}\text { Public Sector } \\
\text { C = A + B }\end{array}$ & $\begin{array}{c}\text { GFCF IBGE } \\
\text { (D) }\end{array}$ & A / C & A / D \\
\hline 1995 & 11,446 & 15,955 & 27.401 & 129,297 & $41.8 \%$ & $8.9 \%$ \\
\hline 1996 & 12,338 & 17,054 & 29,392 & 142,382 & $42.0 \%$ & $8.7 \%$ \\
\hline 1997 & 14,175 & 16,231 & 30,406 & 163,134 & $46.6 \%$ & $8.7 \%$ \\
\hline 1998 & 13,124 & 23,665 & 36,788 & 166,174 & $35.7 \%$ & $7.9 \%$ \\
\hline 1999 & 8,366 & 15,274 & 23,639 & 166,746 & $35.4 \%$ & $5.0 \%$ \\
\hline 2000 & 9,283 & 21,124 & 30,406 & 198,151 & $30.5 \%$ & $4.7 \%$ \\
\hline 2001 & 11,212 & 24,403 & 35,615 & 221,772 & $31.5 \%$ & $5.1 \%$ \\
\hline 2002 & 16,591 & 32,520 & 49,111 & 242,162 & $33.8 \%$ & $6.9 \%$ \\
\hline 2003 & 18,665 & 26,049 & 44,714 & 259,714 & $41.7 \%$ & $7.2 \%$ \\
\hline 2004 & 19,695 & 31,520 & 51,215 & 312,516 & $38.5 \%$ & $6.3 \%$ \\
\hline 2005 & 21,827 & 35,133 & 56,960 & 349,463 & $38.3 \%$ & $6.2 \%$ \\
\hline 2006 & 23,371 & 46,103 & 69,474 & 390,134 & $33.6 \%$ & $6.0 \%$ \\
\hline
\end{tabular}

(*) Union, states and municipalities. Table compiled Gobetti (2010: 54) 
It can be seen the significant relative importance of the public sector in the total GFFC throughout the period, though, end to end, this importance has fallen. Investment spending decreased in both items, Public Administration and Public Enterprises, but overall still achieve a third of Brazilian investments.

Table 4: Biggest and Best in energy sector

\begin{tabular}{|c|c|c|c|c|c|c|}
\hline Ranking & Company & Name & Sector & Type & Control & $\begin{array}{l}\text { Sales Liquid } \\
\text { (In US \$ million) }\end{array}$ \\
\hline 1 & $\begin{array}{c}\text { Petróleo Brasileiro S.A. - } \\
\text { Petrobras }\end{array}$ & Petrobras & Energy & $\begin{array}{l}\text { State- } \\
\text {-owned }\end{array}$ & Brazilian & $100,694.2$ \\
\hline 37 & $\begin{array}{c}\text { Eletropaulo Metropolitana } \\
\text { Eletricidade de São Paulo S.A. }\end{array}$ & Eletropaulo & Energy & Private & $\begin{array}{l}\text { Amer. / } \\
\text { Brazilian }\end{array}$ & 5387.8 \\
\hline 42 & Cemig Distribuição S.A. & $\begin{array}{c}\text { Cemig } \\
\text { Distribuição }\end{array}$ & Energy & $\begin{array}{l}\text { State- } \\
\text {-owned }\end{array}$ & Brazilian & 4661.7 \\
\hline 47 & $\begin{array}{c}\text { Cooperativa de Produção } \\
\text { de Cana-de-Açúcar, Açúcar } \\
\text { e Álcool Est SP }\end{array}$ & $\begin{array}{l}\text { Copersucar } \\
\text { Cooperativa }\end{array}$ & Energy & Private & Brazilian & 4484.9 \\
\hline 56 & $\begin{array}{c}\text { Furnas Centrais } \\
\text { Elétricas S.A. }\end{array}$ & $\begin{array}{l}\text { Eletrobras } \\
\text { Furnas }\end{array}$ & Energy & $\begin{array}{l}\text { State- } \\
\text {-owned }\end{array}$ & Brazilian & 3861.5 \\
\hline 60 & Itaipu Binacional & Itaipu & Energy & $\begin{array}{l}\text { State- } \\
\text {-owned }\end{array}$ & Brazilian & 3652.2 \\
\hline 63 & $\begin{array}{l}\text { Light Serviços de } \\
\text { Eletricidade S.A. }\end{array}$ & Light SESA & Energy & Private & Brazilian & 3564.5 \\
\hline 69 & $\begin{array}{l}\text { Companhia Paulista de } \\
\text { Força e Luz - CPFL }\end{array}$ & CPFL Paulista & Energy & Private & Brazilian & 3064.8 \\
\hline 73 & Copel Distribuição S.A. & Copel & Energy & $\begin{array}{l}\text { State- } \\
\text {-owned }\end{array}$ & Brazilian & 3007.4 \\
\hline 76 & $\begin{array}{l}\text { Companhia Hidro Elétrica } \\
\text { do São Francisco - CHESF }\end{array}$ & Chesf & Energy & $\begin{array}{l}\text { State- } \\
\text {-owned }\end{array}$ & Brazilian & 2803.8 \\
\hline
\end{tabular}

Source: Exame magazine. Available em http://exame.abril.com.br/negocios/melhores-e-maiores/empresas/maiores/1/2011/vendas/-/servicos/-/-, access in 1.20.13.

Another way to grasp the importance of state-owned enterprises (including public banks there) in the Brazilian economy is for their participation in the sectorial structure. According to data collected by Exame Magazine ${ }^{11}$, which publishes the annual ranking of the biggest and best companies operating in Brazil, is possible to observe the integration of state-owned enterprises in the domestic economy. In Table 4, data for the year 2011 show that of the ten largest Brazilian companies in the energy sector for net sales six are state owned. The table also shows the relative position of each company among the five hundred largest companies.

\footnotetext{
${ }^{11}$ Weekly magazine specialized in economic issues and published only in Portuguese. Official site: http:// exame.abril.com.br/.
} 
The same information for the services sector is compiled in Table 5. In this case, among the ten largest companies by net sales five are state owned.

Table 5: Biggest and Best in service sector

\begin{tabular}{|c|c|c|c|c|c|c|}
\hline Ranking & Company & Name & Sector & Type & Control & $\begin{array}{c}\text { Net Sa- } \\
\text { Ies (In Us } \\
\text { \$ Million) }\end{array}$ \\
\hline 20 & Brazilian Post and Telegraph Company & ECT & Services & State-owned & Brazilian & 7238.5 \\
\hline 36 & $\begin{array}{r}\text { Basic Sanitation Company } \\
\text { of the State of São Paulo }\end{array}$ & Sabesp & Services & State-owned & Brazilian & 5438.1 \\
\hline 57 & $\begin{array}{r}\text { International Medical Assistance } \\
101\end{array}$ & Amil & Services & Private & Brazilian & 3729.8 \\
\hline 115 & $\begin{array}{r}\text { Brazilian Company of } \\
\text { airport infrastructure }\end{array}$ & Infraero & Services & State-owned & Brazilian & 1934.3 \\
\hline 131 & Minas Gerais Sanitation Company & COPASA MG & Services & State-owned & Brazilian & 1758.9 \\
\hline 135 & Water and Sewage State Company & Cedae & Services & State-owned & Brazilian & 1735.0 \\
\hline 143 & $\begin{array}{r}\text { Technology In Capture and Proc. } \\
\text { Transactions H.U.A.H. S / A. }\end{array}$ & GET Net & Sevices & Private & BrazilThe- \\
\hline 162 & Rio Cooperative Work Medical & Unimed Rio & Services & Private & Brazilian & 1670.5 \\
\hline
\end{tabular}

Source: Exame magazine. Available in http://exame.abril.com.br/negocios/melhores-e-maiores/empresas/maiores/1/2011/vendas/-/servicos/-/-, access in 1.20.13.

Finally, in Table 6 are listed banking institutions, highlighting the position of two state-owned banks between the top five operating in the country.

Table 6: Major Brazilian Banks - financial intermediation (September 2012)

\begin{tabular}{|c|c|c|c|}
\hline Institutions & Type of capital & $\begin{array}{c}\text { Total assets } \\
\text { Intermediation }\end{array}$ & Total Assets \\
\hline ITAU & Private & $834,587,991$ & $901,420,803$ \\
\hline BB & State-owned & $877,803,258$ & 1046450806 \\
\hline BRADESCO & Private & $644,581,228$ & $741,552,351$ \\
\hline CEF & State-owned & $618,389,559$ & $673,475,813$ \\
\hline SANTANDER & Private & $436,187,777$ & $453,075,553$ \\
\hline
\end{tabular}

Source: Central Bank. Available in http://www4.bcb.gov.br/top50/port/top50.asp, access 1.20.13. 
All these data constitute a specific structural condition. Still, we must emphasize that the state's participation in the Brazilian economy, excluding state-owned enterprises, is significant, but not contrasting with the Centers economies.

The Brazilian public expense is below the world and OCDE average. Expense is cash payments for operating activities of the government in providing goods and services. It includes compensation of employees (such as wages and salaries), interest and subsidies, grants, social benefits, and other expenses such as rent and dividends. The same goes for the rest of the region. The contrast is higher for capitalist Centers countries. The data is in Table 7, taken from the World Developments Indicators of the World Bank.

Table 7: Public Expenses - 1995, 2000, 2004 and 2010

\begin{tabular}{|l|c|c|c|c|}
\hline & 1995 & 2000 & 2004 & 2010 \\
\hline Argentina &.. &.. & 15.28 &.. \\
\hline Brazil &.. & 21.7 & 22.89 & 26.7 \\
\hline Chile &.. &.. & 17.93 & 20.6 \\
\hline Colombia &.. &.. & & 25.4 \\
\hline Mexico & 12.5 & 13.1 & &.. \\
\hline Austria & 42.1 & 39.5 & 42.34 & 38.8 \\
\hline Canada & 23.5 & 18.9 & 17.35 & 18.8 \\
\hline Denmark & 40.8 & 33.9 & 33.58 & 41.1 \\
\hline France & 46.1 & 43.2 & 44.40 & 48.3 \\
\hline Germany & 37.6 & 30.8 & 30.23 & 31.1 \\
\hline Italy & 46.0 & 37.6 & 37.14 & 40.7 \\
\hline Poland &.. &.. & 36.76 & 35.7 \\
\hline Portugal & 36.6 & 36.4 & 39.16 & 43.5 \\
\hline Spain & 36.1 & 30.6 & 25.46 & 30.1 \\
\hline Sweden & 42.5 & 34.2 & 32.34 & 31.0 \\
\hline United Kingdom & 37.8 & 34.5 & 37.49 & 43.2 \\
\hline United States &.. &.. & 20.30 & 25.9 \\
\hline Venezuela, RB & 18.5 & 21.6 & 24.71 &.. \\
\hline World &.. &.. & 26.48 & 29.1 \\
\hline OECD members &.. &.. & 27.57 & 29.8 \\
\hline Source. IF and & 6.5 & & \\
\hline
\end{tabular}

Source:. IMF and World Bank and OECD GDP estimations, WDI.

Therefore, the specificity of the State in the dependent economies and the Brazilian economy in particular is not in the level of State direct resources in the economy, but the nature of this participation. Unfortunately, there are no statistics available for international comparison of the weight of state enterprises, which would give the differences in function and form of state regulation in different capital reproduction patterns.

In Reis (2008) there are data supporting our interpretation for the Brazilian 
economy. The data are presented in Tables 8 and 9. The participation of the public sector in total investment is significant, reaching $36.02 \%$ of the total in the period 1968-1979, which includes the "miracle" of Brazilian growth. In this period, there is peak participation of state companies that reach about $18 \%$ of total GFFC. In the remaining periods this participation drops, but following significant.

In addition to the quantitative direct participation, there is the inducing effect to the total investment also comparatively larger. Our interpretation suggests structural complementary of public and private investments in Brazil. Thus, in periods of expansion of public investment there is greater overall effect to that seized by calculating the multiplier / Keynesian accelerator.

Public investment has complementary effects on private investment because, on the demand side, sustains the economic cycle and expands and integrates the market, and on the supply side, affects the overall productivity of the economy and anticipates investment cycles (if there is any economic planning). This investment is able to move the production structure for capital-intensive sectors through stateowned enterprises procurement policies and government investments in infrastructure for the benefit of domestic producers, impacting the amount and allocation of investments in general. The volume and composition of public investment is essential for the investment rate, for its sectorial distribution and productivity of the whole economy (REIS, 2008, p. 57).

However, no data are available for this evidence, which we can abstract for our central hypothesis support that is simply to show that the state's role in the economies of Latin America is enlarged compared to the economies of the centers.

Tables 8 and 9 show data used to assess the inductive importance of public investment. Table 8 compares the changes in real GDP with increases in real GFFC. The periods are regular in the specialized literature and translate, in general, a clear relationship between changes in GDP and GFCF.

Table 8: Changes in real GDP and GFCF - 1950/-2006

In percentages, US \$ constant 1980

\begin{tabular}{|c|c|c|c|c|}
\hline Per slimes & $\begin{array}{l}\text { Variation of real } \\
\text { GDP }\end{array}$ & $\begin{array}{c}\text { variation real GDP } \\
\text { Manufacturing Industry }\end{array}$ & $\begin{array}{c}\text { Variation of real } \\
\text { GFCF }\end{array}$ & GFCF / GDP \\
\hline \multicolumn{5}{|c|}{ 1950-1967 } \\
\hline Average & 6.23 & 7.65 & 7.05 & 18.34 \\
\hline Standard deviation & 2.97 & 5.21 & 10.12 & 1.96 \\
\hline \multicolumn{5}{|c|}{ 1968-1979 } \\
\hline Average & 8.93 & 9.89 & 10.81 & 22.85 \\
\hline Standard deviation & 2.91 & 4.45 & 7.35 & 1.61 \\
\hline \multicolumn{5}{|c|}{ 1980-1989 } \\
\hline Average & 3.01 & 1.89 & 0.52 & 18.55 \\
\hline Standard deviation & 4.61 & 7.04 & 11.97 & 2.45 \\
\hline \multicolumn{5}{|c|}{ 1990-2006 } \\
\hline Average & 2.27 & 1.59 & 1.41 & 14.58 \\
\hline Standard deviation & 2.50 & 4.96 & 7.39 & 1.04 \\
\hline
\end{tabular}

Source: Compiled from Reis (2008, p. 62). 
Table 9: Public investment participation in GFCF of the Brazilian economy for periods: 1950-2006

In percentage of GDP, US \$ constant 1980 (except share of GFCF on GDP of Brazil)

\begin{tabular}{|c|c|c|c|c|c|c|c|c|}
\hline \multirow{3}{*}{ Periods } & \multicolumn{6}{|c|}{ GFFC by type of investor ( $\%$ of GDP) } & \multirow{2}{*}{\multicolumn{2}{|c|}{$\begin{array}{c}\text { GFFC by productive branch } \\
\text { (\% Of GDP) }\end{array}$}} \\
\hline & \multicolumn{3}{|c|}{ Public sector ( $\%$ of GDP) } & \multirow[b]{2}{*}{$\begin{array}{c}\text { Sector } \\
\text { Public } \\
\text { Total }\end{array}$} & \multirow[b]{2}{*}{$\begin{array}{l}\text { Private } \\
\text { Sector }\end{array}$} & \multirow{2}{*}{$\begin{array}{c}\text { Sector } \\
\text { Public / } \\
\text { Total GFCF }\end{array}$} & & \\
\hline & $\begin{array}{c}\text { GFFC / } \\
\text { GDP (\%) }\end{array}$ & $\begin{array}{l}\text { Manages } \\
\text { Publiction }\end{array}$ & $\begin{array}{l}\text { Business } \\
\text { State }\end{array}$ & & & & Construction & $\begin{array}{c}\text { Machine and } \\
\text { Equipment }\end{array}$ \\
\hline \multicolumn{9}{|c|}{ 1950-1967 } \\
\hline Average & 18.34 & 4.35 & 1.22 & 5.58 & 12.70 & 31.07 & 11.40 & 6.57 \\
\hline $\begin{array}{l}\text { Standard } \\
\text { Deviation }\end{array}$ & 1.96 & 0.71 & 0.74 & 1.02 & 2.56 & 7.69 & 1.32 & 0.82 \\
\hline \multicolumn{9}{|c|}{ 1968-1979 } \\
\hline Average & 22.85 & 4.21 & 4.30 & 8.31 & 14.68 & 36.02 & 13.65 & 8.83 \\
\hline $\begin{array}{l}\text { Standard } \\
\text { Deviation }\end{array}$ & 1.61 & 0.91 & 1.74 & 1.74 & 1.42 & 6.15 & 0.95 & 0.97 \\
\hline \multicolumn{9}{|c|}{ 1980-1989 } \\
\hline Average & 18.55 & 2.25 & 2.94 & 5.19 & 13.36 & 27.85 & 12.51 & 5.52 \\
\hline $\begin{array}{l}\text { Standard } \\
\text { Deviation }\end{array}$ & 2.45 & 0.39 & 0.96 & 0.97 & 1.64 & 2.64 & 1.25 & 1.18 \\
\hline \multicolumn{9}{|c|}{ 1990-2006 } \\
\hline Average & 14.58 & 2.08 & 1.14 & 3.22 & 11.75 & 21.64 & 8.66 & 5.07 \\
\hline $\begin{array}{l}\text { Standard } \\
\text { Deviation }\end{array}$ & 1.04 & 0.47 & 0.58 & 0,93 & 1.39 & 6.79 & 2.00 & 1.14 \\
\hline
\end{tabular}

Source: Compiled from Reis (2008, p. 62).

In Table 9 this relationship is broken down to identify the relative importance of public investment. It is evident that in periods of higher growth, such as the "miracle", for example, the share of public sector investment expands.

Finally, it is important to resume the issue of transfers to the private sector of State public resources obtained by means of taxation, and / or monetary and financial transfers. These are the transfers that make up the dispossession of social resources for private activity, according to Harvey (2004). The transfer enhances the concentration of wealth, it means less purchasing power for workers in general and even for small entrepreneurs (see Figure 1). And, consequently, it affects the dynamics of the economy by compression the workers spending.

In the Brazilian economy, the dispossession degree can be approached in two ways. The first is by the measurement of income concentration effect that the tax 
imposes on individuals. ${ }^{12}$ The second way is by the management of public debt, which benefits the public security holders, including the security of a financial investment without risks.

Figure 1: Income redistribution Stages

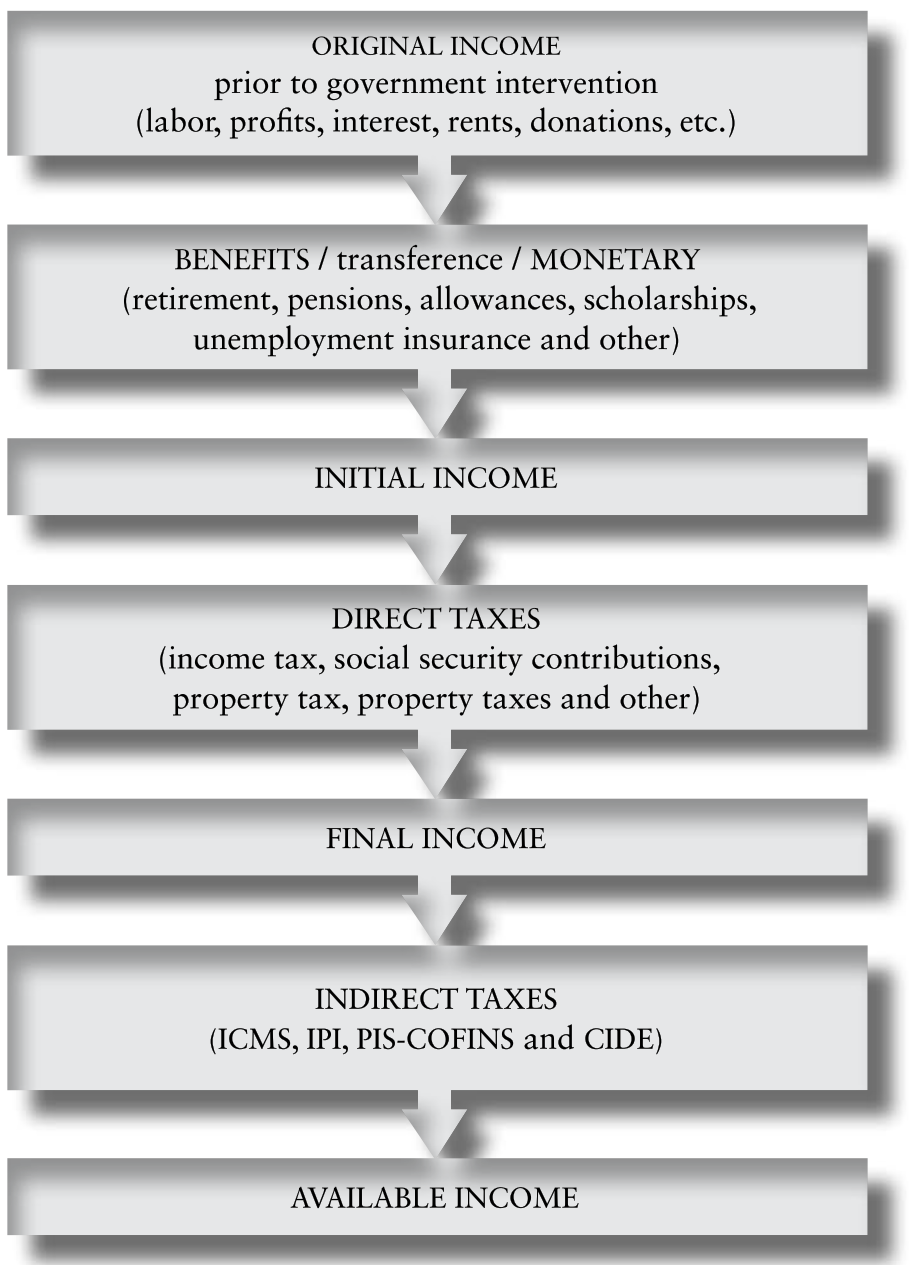

Source: Compiled by Silveira (2010, p. 80). Original picture Lakin (2002).

\footnotetext{
${ }^{12}$ We are highlighting only the concentrator effects of taxes in the Brazilian economy that reinforce the argument presented here that capitalist development in the periphery has structural mechanisms of concentration of wealth related to the functioning of the state. A comprehensive analysis of the social effects of the functioning of the state apparatus would require also investigate the transfer of benefits, reduce or cancel the concentrating effect of tax collection. The analysis by Silveira (2010) shows a final result slightly redistributive virtually neutral, State global action regarding the collection and transfer.
} 
About the first way, Silveira (2010) shows that the tax collection system in Brazil has overall income concentrator effect (Graph 1). He estimates a high degree of regressivity of the direct and indirect tax burden on families, only offset by the progressivity of direct taxes, results in the regressivity of the tax system.

Graph 1: Tax burden on total income

Tenths of a per capita family income available ${ }^{13}$

(Less income tax)

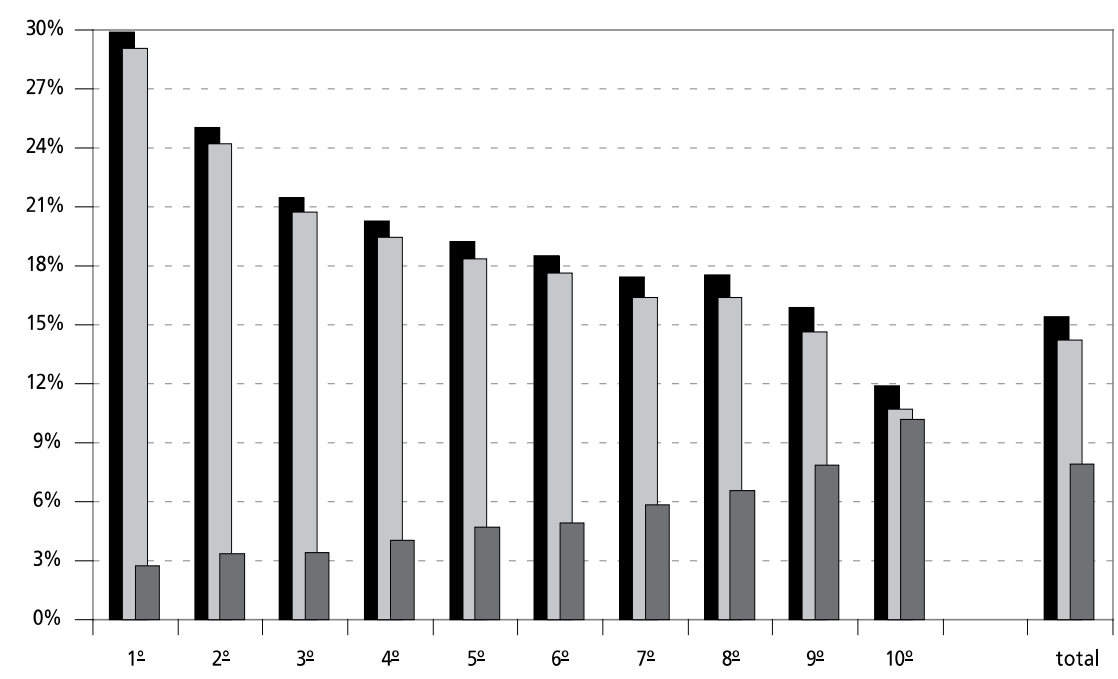

Source: Compiled from Silveira (2010: 103). POF 2002-2003, IBGE.

In Graph 1, it can be seen that the poorest $10 \%$ have a total tax burden of about $32 \%$, continuously falling to represent only $12 \%$ for the richest $10 \%$ of the population. Of course, the regressive taxes, other things equal, including transfers, will limit the ability of population expenditure as a whole, but proportionately much more to the population of workers.

On the other hand, Santos (2010) shows that the dynamics of public debt is intensely concentrating, the ownership structure of debt securities in a few social groups, notably banks and pension funds. Considering that the funds are generally managed by the banks, the dynamics of public debt transfers significant resources from the public to the private sphere.

The theft is configured when resources are transferred to the private sector without counterparts in social actions, if justifying the difficulties that all or capital segments have to play, or simply by particular advantages obtained by means of direct political action in the state apparatus.

\footnotetext{
${ }^{13}$ In the graph, the darker bar is the final indirect taxation. The clearest bar is the initial indirect taxation; the intermediate color bar is the initial direct taxation.
} 
Table 10 shows a set of government expenditure and interest expense in Brazil compared to selected countries. The data are timely, but serve to scale the relative importance of financial transfers for interest payments. The ratio net i nterest paid / GDP is the highest of the entire selected group, reaching 5.4\%.

Table 10: Featured expenditure of general government in Brazil and in selected countries, 2007 and 2008 (\% of GDP)

\begin{tabular}{|l|c|c|c|c|c|c|}
\hline \multicolumn{1}{|c|}{ Country } & $\begin{array}{c}\text { Government } \\
\text { added value } \\
2007\end{array}$ & $\begin{array}{c}\text { Government } \\
\text { consumption } \\
\text { intermediary 2007 }\end{array}$ & $\begin{array}{c}\text { TAP } \\
\text { Assistance } \\
\text { Security } \\
2007\end{array}$ & $\begin{array}{c}\text { GFFC in } \\
2007\end{array}$ & $\begin{array}{c}\text { Public } \\
\text { Sector } \\
\text { Net debt } \\
2008\end{array}$ & $\begin{array}{c}\text { Net } \\
\text { interest } \\
\text { paid in } \\
2008\end{array}$ \\
\hline Germany & 8.3 & 4.2 & 18.4 & 1.5 & 45.1 & 2.3 \\
\hline Belgium & 13.4 & 3.5 & 17.3 & 1.6 & 73.6 & 3.6 \\
\hline Brazil & 13.3 & 7.0 & 14.8 & 1.8 & 37.6 & 5.4 \\
\hline Canada will & 13.5 & 8.9 & 11.0 & 3.0 & 21.7 & 0.2 \\
\hline South Korea & 9.4 & 3.8 & 3.6 & 4.9 & -37.4 & -1.5 \\
\hline Spain & 11.9 & 5.1 & 12.7 & 3.8 & 22.9 & 1.0 \\
\hline USA & 11.5 & 8.5 & 12.6 & 2.6 & 48.2 & 1.9 \\
\hline France & 15.6 & 5.0 & 18.9 & 3.3 & 41.9 & 2.7 \\
\hline Greek & 13.1 & 5.1 & 17.4 & 3.0 & 72.7 & 4.1 \\
\hline Hungary & 14.6 & 6.7 & 16.6 & 3.6 & 51.3 & 3.7 \\
\hline Ireland & 10.3 & 5.3 & 10.3 & 4.4 & 11.1 & -0.3 \\
\hline Italia & 13.0 & 5.2 & 18.1 & 2.3 & 89.7 & 4.9 \\
\hline Jap will & 9.3 & 3.3 & 12.2 & 3.1 & 84.3 & 0.8 \\
\hline Norway & 14.1 & 6.1 & 14.1 & 3.1 & -125.3 & -3.8 \\
\hline Polonies & 12.5 & 6.0 & 14.8 & 4.2 & 20.2 & 1.9 \\
\hline Portugal & 14.6 & 4.1 & 16.3 & 2.3 & 47.9 & 3.0 \\
\hline United Kingdom & 11.9 & 11.7 & 13.4 & 1.8 & 33.6 & 2.0 \\
\hline Sweden & 17.8 & 9.4 & 16.8 & 3.1 & -13.8 & 0.5 \\
\hline
\end{tabular}

Source: Compiled from Santos (2010, p. 58). IBGE and OECD data.

On the other hand, government securities ownership is significantly concentrated in large companies at the financial and non-financial sectors, in addition to pension funds institutional investors. This information is depicted in Graph 2.

All these theoretical and historical elements evidently require deepening. However, the records presented here are sufficient to set the specificity of capital reproduction in Brazil and, by extension, in the Latin American periphery of capitalism, regardless the regional hierarchy of national economies. 


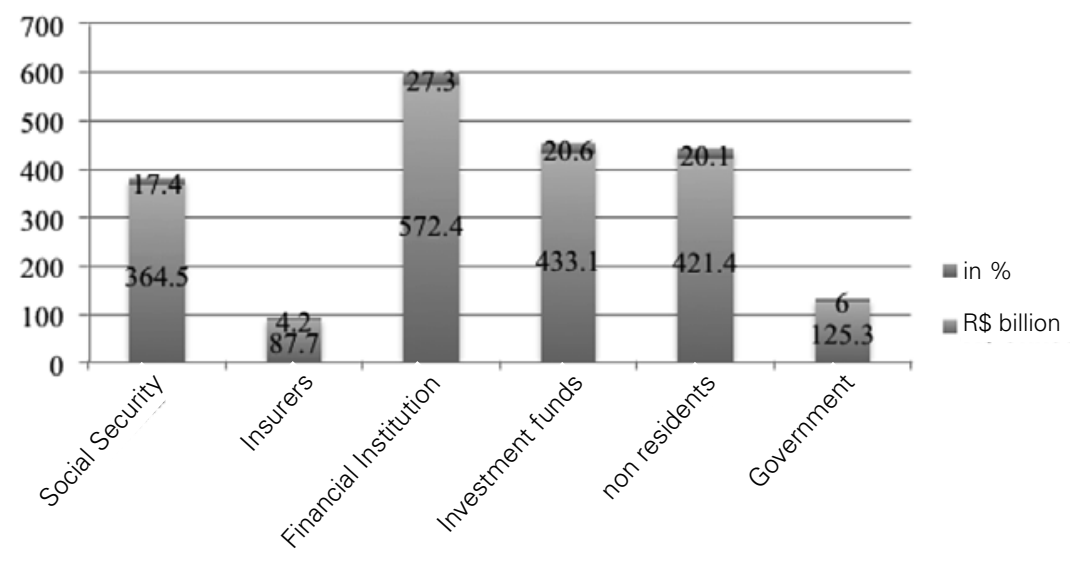

Source: STN (the Brazilian National Trasury), 2014

\section{CONCLUSIONS}

The objective of this paper is to show that the concentration of income / wealth has important dynamic implications for societies in general, especially for the dependents. These implications emphasize the expanded role and the nature of the State compared to the societies of the Centers of capitalism.

This feature far to mitigate the universal nature of capitalism to concentrate wealth in accordance thoroughly proven by Marx in The Capital, turns out to intensify it. Indeed, the economic operation of the State in the Brazilian Economy shows that both its form of financing of regular activities as public debt management have global wealth concentration effect.

This is reflected in the relative position of Brazil in the social hierarchy of global capitalism. In Latin America, Brazil has one of the highest Gini index: 53.9. ${ }^{14}$ In Araújo and Almeida Filho (2012) there is a synthesis of social indicators showing the enormous social disparity between the country and those considered developed in terminology the World Bank.

So there are many phenomena to prove that capitalist development in Latin America, despite the good macroeconomic performance since 2007, has a peculiar dynamic. If these elements can be added to those presented in Izyumov and Vahaly (2012), which indicate an increase in the exploitation in developing economies and economies in transition then we will have a general framework to indicate that structural determinants of global capitalism are still the same.

${ }^{14}$ Data available on the UN 2011 Human Development Report. 


\section{REFERENCES}

Almeida Filho, N. (2013) "Superexploitation of the workforce and concentration of wealth: key issues for development policy in Brazilian peripheral Capitalism”. World Review of Political Economy, V.4, p.4-24.

Almeida Filho, Niemeyer (2012) "Notes on the theoretical basis of the Marxist theory of dependency". Development and Dependency: the actuality of Marini's thought. Curitiba: Publisher CRV, p. 3343.

Almeida Filho, Niemeyer and Leda M. Paulani (2011) "Regulation and accumulation by dispossession: reflection on the essentiality of the theses of financialization and State nature of contemporary capitalism.” Economy and Society (UNICAMP Form.) 20: 243- 272.

Araújo, Priscilla and Almeida Filho, Niemeyer. (2012) "Disparities in global growth.” Temporalis 23: 13-43.

Arrighi, Giovanni (1995) “The global inequality in income distribution and the future of socialism." In Emir Sader (Ed.) The World After the Fall. London: Peace and Earth.

Carcanholo, Reinaldo A. (2008) “Contemporary capitalism and productive work". Journal of Economics (Curitiba) special number: 205-221.

Eichengreen, Barry (2015) Hall of Mirrors - the great depression, the great recession, and the uses and misuses - of history. Oxford University Press.

Ferreira, Carla; Jaime Osorio; Matias Luces (eds.) Pattern of capital reproduction: the Marxist theory of dependency contributions London: Boitempo: 2012

Gobetti, Sergio W. (2010) "State and fiscal adjustment: an analysis of the contribution of federal enterprises to the macroeconomic balance”. Economy and Society, Campinas, v. 19, no. 1 (38), p. 29-58, April

Harvey, David (2004) The New Imperialism. São Paulo: Loyola Editions.

Izyumov, Alexei and John Vahaly (2012) "Globalization and rates of surplus value across the world." Presented at 2012 in IIPPE Paris Conference.

Kalecki, Michael (1977 [1968]) “The Marxist equations of reproduction and the modern economy,” In Dynamics Cycle and the Capitalist Economies. London: Hucitec: pp.1-9.

Keynes, John M. (1985 [1936]) The General Theory of Interest, Employment and Money. Collection Economists. London: Cultural April.

Lakin, Caroline (2002) "The effects of taxes and benefits on household income (2000-01)" Office for National Statistics, United Kingdom, Economic Trends, No. 582, May.

Marini, Ruy M. (2000 [1973]) Dialectic of Dependency. Petropolis: Voices.

Possas, Mario L. (1987) The Dynamics of Capitalist Economy - A Theoretical Approach. Sao Paulo: Brasiliense.

Reis, CF Borja (2008) "Public investment and economic development: applied analysis to Brazil between 1950 and 2006, based on a Keynesian theoretical and structuralist”. OIKOS, 10 pp. 53-77.

Santos, Claudio HM (2010) “An overview of the Brazilian public finances 1995/2009," in Jorge Abraham de Castro, Claudio Hamilton Matos dos Santos and Jose Aparecido Carlos Ribeiro (eds) Taxation and Equity in Brazil: a Record of IPEA Reflection in 2008-2009. Brasilia: IPEA: pp 19-66

Silveira, Fernando G. (2010) “Taxation, social security and social assistance: distributional impacts.” in Jorge Abraham de Castro, Claudio Hamilton Matos dos Santos and Jose Aparecido Carlos Ribeiro (eds) Taxation and Equity in Brazil: a Record of IPEA Reflection in 2008-2009. Brasilia: IPEA: pp.67-124.

Traspadini, R. and J.P. Stédile (2005) Marini - Life and Work. London: Popular Expression.

Valencia, AS; EC Martins; T. dos Santos; and E. Sader, E. (2009) Latin America and the Challenges of Globalization: Essays Dedicated to Marini. London: Boitempo. 